\title{
Manajemen Hipotermia pada Pasien Cedera Kepala: Suatu Tinjauan Literatur
}

\author{
Ismail Fahmi \\ Mahasiswa Magister Keperawatan Medikal Bedah, Fakultas Ilmu Keperawatan, Universitas Indonesia; \\ fahmi270684@gmail.com (koresponden) \\ Amelia Ganefianty \\ Mahasiswa Magister Keperawatan Medikal Bedah, Fakultas Ilmu Keperawatan, Universitas Indonesia \\ Ely Nurachmah \\ Departemen Keperawatan Medikal Bedah, Fakultas Ilmu Keperawatan, Universitas Indonesia
}

\begin{abstract}
Head injury is a crucial public health problem and causes social and economic problems throughout the world. Increased brain blood volume associated with increased body temperature will increase intracranial pressure (ICP) and cause the brain at risk of other injuries. This paper aims to identify the effect of hypothermia management on head injury patients. This article was a review of literature from several data bases, Pubmed, EBSCO Host, Google scholar, and Web of Science. Article search was restricted from 2007 to 2018 using the keyword "head injury", "hypothermia management", "hypothermia in head injury". The search results of the article were that management of hypothermia in head injury patients can reduce metabolic requirements, cerebral metabolic rate for oxygen $\left(\mathrm{CMRO}_{2}\right)$, excitotoxicity, reduce glutamate release, reduce free radical formation, reduce edema formation, stabilize membranes, maintain adenosine triphosphate (ATP), reduce influx $\mathrm{Ca}$, and intracranial pressure so that it can reduce brain damage and risk of death.
\end{abstract}

Keywords: head injury; hypothermia in head injury; hypothermia management

\begin{abstract}
ABSTRAK
Cedera kepala merupakan masalah kesehatan masyarakat yang krusial dan menyebabkan permasalahan sosial serta ekonomi di seluruh dunia. Peningkatan volume darah otak yang dihubungkan dengan kenaikan suhu tubuh akan meningkatkan tekanan intrakranial (intracranial pressure/ICP) dan menyebabkan otak berisiko terkena cedera lain. Tulisan ini bertujuan untuk mengidentifikasi pengaruh manajemen hipotermia pada pasien cedera kepala. Tulisan ini merupakan tinjauan literature dari beberapa data base yaitu Pubmed, EBSCO Host, Google scholar, dan Web of Science. Penelusuran artikel dibatasi pada tahun 2007 sampai dengan tahun 2018 dengan menggunakan kata kunci "cedera kepala", "manajemen hipotermia", "hipotermia pada cedera kepala". Hasil penelusuran artikel adalah manajemen hipotermia pada pasien cedera kepala dapat berefek mengurangi kebutuhan metabolik, cerebral metabolic rate for oxygen $\left(\mathrm{CMRO}_{2}\right)$, eksitotoksisitas, menurunkan pelepasan glutamat, menurunkan pembentukan radikal bebas, mengurangi pembentukan edema, stabilisasi membran, memelihara adenosine triphosphate (ATP), menurunkan influx $\mathrm{Ca}$, dan tekanan intrakranial sehingga dapat mengurangi kerusakan otak dan risiko kematian.
\end{abstract}

Kata kunci: cedera kepala; hipotermia pada cedera kepala; manajemen hipotermia

\section{PENDAHULUAN}

Cedera kepala merupakan masalah kesehatan masyarakat yang krusial dan menyebabkan permasalahan sosial serta ekonomi di seluruh dunia ${ }^{(1)}$. Pada tahun 2013, terdapat sekitar 2,8 juta pasien dengan cedera kepala masuk ke rumah sakit di Amerika Serikat, sekitar 500.000 orang meninggal, 282.000 menjalani rawat inap, dan 2,5 juta pasien dirawat di Instalasi Gawat Darurat (IGD). Tahun 2007-2013, tingkat kunjungan cedera kepala yang masuk ke IGD meningkat sebesar $47 \%^{(2)}$.

Cedera kepala dapat meningkatkan angka kematian dalam jangka anjang dan juga menurunkan angka harapan hidup ${ }^{(3)}$. Hal ini disebabkan karena cedera kepala dapat meningkatkan angka kejadian kejang, gangguan tidur, penyakit neurodegeneratif, disrefulasi endokrin, gangguan psikoatrik, disfungsi seksual, inkontinensia blader dan bowel, serta disregulasi metabolik sistemik yang dapat menetap meskipun beberapa bulan bahkan beberapa tahun pasca cedera kepala ${ }^{(3)}$.

Pengelolaan pasien cidera kepala harus komprehensif, dimulai dari tempat kecelakaan, selama transportasi, kamar operasi, dan pengelolaan pasca bedah (pengelolaan perioperatif) ${ }^{(4)}$. Pasien dengan risiko hipertensi intrakranial, seperti pasien cidera kepala, secara nyata dipengaruhi oleh perubahan suhu tubuh karena aliran darah otak (cerebral blood flow/CBF) akan meningkat seiring dengan peningkatan suhu tubuh. Peningkatan volume darah otak yang dihubungkan dengan kenaikan suhu tubuh akan meningkatkan tekanan intrakranial (intracranial pressure/ICP) dan menyebabkan otak berisiko terkena cedera lain. Karena itu, 
hipertermia meningkatkan resiko kerusakan sel neuron dan menempatkan pasien beresiko terjadinya cedera otak sekunder melalui adanya peningkatan $\mathrm{ICP}^{(5)}$.

Hipertermia postiskemik dihubungkan dengan peningkatan ukuran infark dan outcome yang lebih buruk. Walaupun pengendalian yang ketat kearah suhu tubuh yang normal telah dicatat sebagai strategi terapi yang penting pada Guideline for Management Severe Head Injury, akan tetapi, strategi managemen hipotermia sebagai terapi klinis untuk praktisi sering dinilai tidak efektif dan mungkin merupakan kontraindikasi pada pasien cidera kepala ${ }^{(6)}$. Tulisan ini akan membahas mengenai bagaimana efek manajemen hipotermi pada pasien cedera kepala.

\section{METODE}

Tulisan ini merupakan tinjauan literature dari beberapa data base yaitu Pubmed, EBSCO Host, Google scholar, dan Web of Science. Penelusuran artikel dibatasi pada tahun 2007 sampai dengan tahun 2018 dengan menggunakan kata kunci "cedera kepala", "manajemen hipotermia", "hipotermia pada cedera kepala". Proses pencarian literatur dapat dilihat dalaam Gambar 1.

256 artikel melalui pencarian database (EBSCO,

PubMed, Google Scholar, Web of Science)

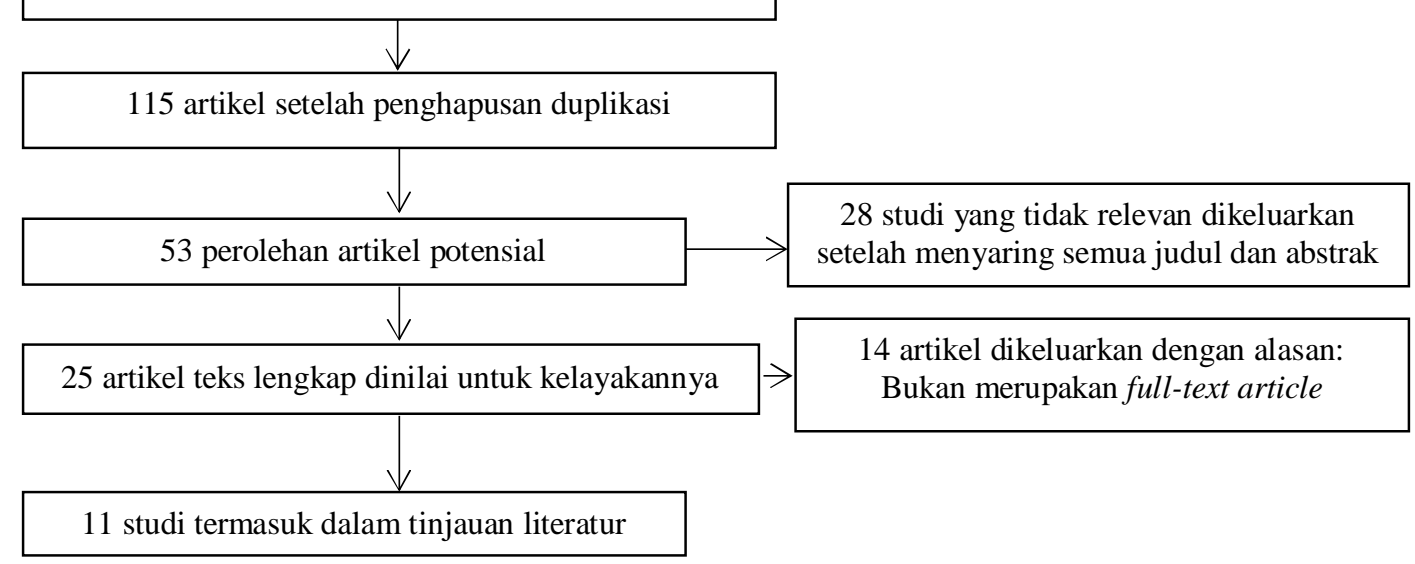

Gambar 1. Hasil pencarian dalam database terkait dengan manajemen hipotermia pada pasien cedera kepala

\section{HASIL}

Pasien dengan hipertensi intrakranial, seperti pasien cidera kepala, secara nyata dipengaruhi oleh perubahan suhu tubuh karena aliran darah otak (cerebral blood flow/CBF) akan meningkat seiring dengan peningkatan suhu tubuh. Peningkatan volume darah otak yang dihubungkan dengan kenaikan suhu tubuh akan meningkatkan tekanan intrakranial (intracranial pressure/ICP) dan menyebabkan otak berisiko terkena cedera lain. Karena itu, hipertermia meningkatkan resiko kerusakan sel neuron dan menempatkan pasien beresiko terjadinya cedera otak sekunder melalui adanya peningkatan $\mathrm{ICP}^{(7)}$. Mekanisme proteksi otak hipotermi adalah mengurangi kebutuhan metabolik, cerebral metabolic rate for oxygen (CMRO2), eksitotoksisitas, menurunkan pelepasan glutamat, menurunkan pembentukan radikal bebas, mengurangi pembentukan edema, stabilisasi membran, memelihara adenosine triphosphate (ATP), menurunkan influx $\mathrm{Ca}$, dan tekanan intrakranial. Sedangkan komplikasi hipotermi berat adalah pneumonia, sepsis, disritmia jantung, hipotensi, masalah perdarahan dan menggigil. Temperatur ideal untuk hipotermia terapeutik adalah $35^{\circ} \mathrm{C}^{(8)}$. Selain itu, hipertermia post iskemik dihubungkan dengan peningkatan ukuran infark dan outcome yang lebih buruk ${ }^{(5)}$.

Studi systematic review menjelaskan bahwa pasien yang dilakukan early hipotermia dalam waktu kurang dari 24 jam, dapat berefek menurunkan risiko kematian akibat cidera kepala ${ }^{(8)}$. Selanjutnya, mekanisme patofisiologi yang mendasarinya adalah dimana hipotermia menurunkan aktivitas metabolik dan fungsional dari otak. Koefisien temperatur (Q10) menunjukkan faktor dengan mana cerebral metabolic rate for oxygen (CMRO2) berubah setiap perbedaan temperatur 10 derajat. Untuk kebanyakan reaksi biologis, Q10 nilainya kira-kira 2 (penurunan $50 \% \mathrm{CMRO} 2$ untuk setiap penurunan temperatur $10^{\circ} \mathrm{C}$ ). Jadi otak yang normotermik $\left(37^{\circ} \mathrm{C}\right)$ dapat mentolerir iskemia komplit yang berlangsung selama 5 menit, pada suhu $27^{\circ} \mathrm{C}$ otak dapat mentolerir iskemia yang berlangsung selama 10 menit $^{(5)}$. Dalam penelitian lain juga disebutkan bahwa penanganan cidera kepala dengan terapi hipotermia pada suhu $32-34^{0} \mathrm{C}$ selama lebih dari 48 jam efektif 
menurunkan kerusakan otak dan kematian ${ }^{(6)}$. Mekanisme terapi hipotermi dalam mencegah kerusakan otak di jelaskan dalam Gambar 2.

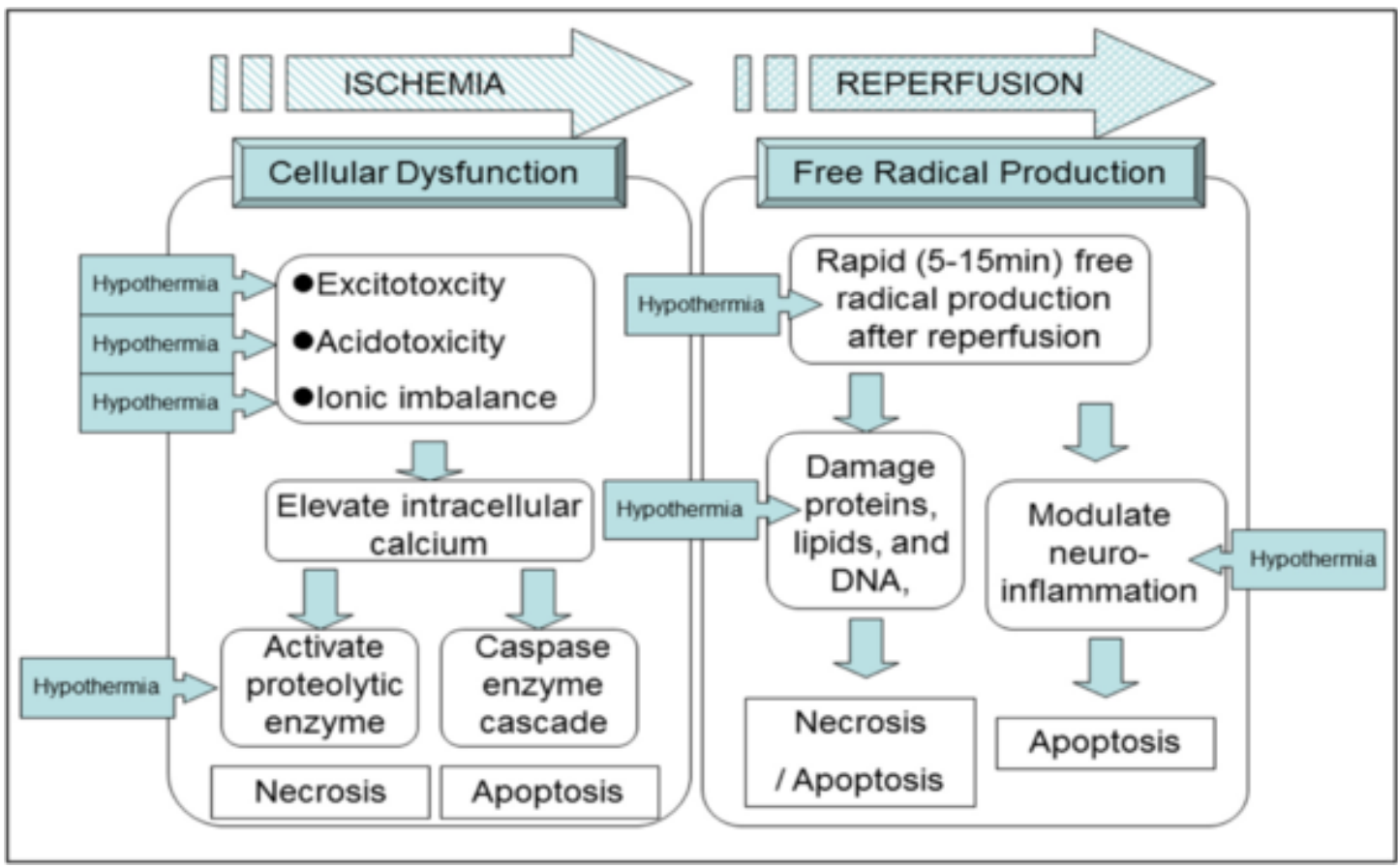

Gambar 2. Mekanisme terapi hipotermi dalam mencegah kerusakan otak ${ }^{(9)}$

Surface cooling merupakan salah satu intervensi yang dapat dilakukan pada pasien cidera kepala, satu penelitian randomized controlled trial yang bertujuan menilai keefektifan surface cooling dengan kompres dingin untuk menurunkan suhu tubuh pasien cidera kepala. Penelitian dilakukan pada pada 47 pasien cidera kepala dengan terpasang ventilator, kompres dingin dilakukan selama 3 jam, hasil penelitian menunjukan Surface cooling dengan kompres dingin efektif menurunkan suhu tubuh pasien ${ }^{(4)}$. Sebuah penelitian lain menjelaskan bahwa surface cooling dengan target suhu 32-34 ${ }^{0} \mathrm{C}$ efektif mencegah kerusakan otak ${ }^{(9)}$.

Proses rewarming penting dilakukan setelah dilakukan terapi hipotermia, pasien dengan hipertensi intrakranial diketahui mempunyai refleks meningkatkan ICP selama rewarming yang cepat. Menggigil selama rewarming akan meningkatkan konsumsi oksigen dan harus dihentikan dengan pemberian sedasi dan pelumpuh otot. Alat penghangat adalah pemanas cairan, sikuit humidifier, selimut air panas, forced air warming blankets (paling cepat), lampu pemanas infrared. Rewarming dilakukan bila ICP $<20 \mathrm{mmHg}$ (stabil untuk 48 jam). Dianjurkan rewarming yang lambat lebih dari 12 jam dengan kecepatan $0,10 \mathrm{C} / \mathrm{jam}$, ada yang menyarankan rewarming dengan kecepatan $10 \mathrm{C}$ setiap 3-4 jam, $10 \mathrm{C} / \mathrm{hari}, 0,50 \mathrm{C}$ dalam $2 \mathrm{jam}$. Rewarming yang lambat $0,25^{\circ} \mathrm{C} / \mathrm{jam}$ memberikan proteksi yang maksimal ${ }^{(8)}$. Dari paparan beberapa penelitian, penulis menyimpulkan bahwa bahwa terapi hipotermi efektif dalam menurunkan tekanan intrkranial pada pasien cidera kepala.

\section{PEMBAHASAN}

Pengendalian normotermia (pencegahan panas dengan pendinginan intravaskuler) efektif dalam mengurangi panas dan beratnya cedera otak sekunder setelah cedera kepala berat akibat dari penurunan tekanan intrakranial dan panas. Telah lama diketahui dari beberapa penelitian eksperimental bahwa hipotermia adalah neuroprotektif setelah iskemia otak. Mekanisme bagaimana hipotermia mempunyai efek proteksi otak, belum jelas. Kemungkinan karena menurunkan metabolisme otak, mencegah apoptosis, mengurangi disfungsi mitokhondria mengurangi produksi radikal bebas dan juga mengurangi kerusakan oksidatif DNA, menurunkan influks $\mathrm{Ca} 2+$, menurunkan pelepasan exitatory amino acids (EAA) glutamat, mencegah peroksidasi lipid, menurunkan pembentukan edema ${ }^{(5)}$.

Hipertermi pada pasien dengan cidera kepala terjadi karena hipoksia jaringan otak akibat dari penurunan CBF yang signifikan dan terjadinya pembentukan edema, hal ini menyebabkan terjadinya peningkatan suhu lebih tinggi daripada suhu inti, hipotesis lain mengungkapkan peran potensial dari produk degradasi heme. Molekul heme terdegradasi oleh heme oxygenase menjadi biliverdin, besi, dan karbon monoksida (CO), dimana karbon monoksida meningkatkan suhu tubuh lebih dari $1^{\circ} \mathrm{C}^{(7)}$. Sebuah studi lain melaporkan bahwa $50 \%$ pasien 
dengan perdarahan subarachnoid mengalami hipertermia. Kemudian pada pasien ditemukan terjadinya leukositosis, Leukositosis merupakan salah satu komplikasi cedera otak. Epinefrin dan kortisol dianggap salah satu yang berperan di dalam terjadinya leukositosis. Selain itu, masih ada mekanisme lain yang diperantarai oleh mediator-mediator inflamasi ${ }^{(10)}$. Kenaikan jumlah leukosit tersebut berhubungan dengan outcome yang buruk pada pasien cedera otak ${ }^{(11)}$. Akumulasi leukosit ke area otak yang cedera sangat penting untuk tingkat peradangan dan kerusakan otak sekunder ${ }^{(12)}$.

Inflamasi, seperti halnya organ lain, juga merupakan bagian terpenting dari patomekanisme cedera otak traumatika. Pada suatu kejadian cedera otak perlu terjadi keseimbangan antara sitokin yang menimbulkan reaksi inflamasi, dengan tujuan untuk membatasi dan memulihkan kerusakan yang terjadi, serta sitokin anti inflamasi Interleukin 10 (IL-10) yang membatasi agar kerja dari sitokin inflamasi ini tidak berlebihan, yang bila terjadi justru akan menimbulkan efek yang merugikan ${ }^{(13)}$.

Mekanisme proteksi otak hipotermi adalah mengurangi kebutuhan metabolik, cerebral metabolic rate for oxygen (CMRO2), eksitotoksisitas, menurunkan pelepasan glutamat, menurunkan pembentukan radikal bebas, mengurangi pembentukan edema, stabilisasi membran, memelihara adenosine triphosphate (ATP), menurunkan influx $\mathrm{Ca}$, dan tekanan intrakranial. Pasien yang dilakukan early hipotermia dalam waktu kurang dari 24 jam, dapat berefek menurunkan risiko kematian akibat cidera kepala ${ }^{(8)}$. Selain itu, manajemen hipotermia dengan target suhu $32-34{ }^{0} \mathrm{C}$ efektif mencegah kerusakan otak ${ }^{(9)}$.

\section{KESIMPULAN}

Manajemen hipotermia pada pasien cedera kepala dapat berefek mengurangi kebutuhan metabolik, cerebral metabolic rate for oxygen (CMRO2), eksitotoksisitas, menurunkan pelepasan glutamat, menurunkan pembentukan radikal bebas, mengurangi pembentukan edema, stabilisasi membran, memelihara adenosine triphosphate (ATP), menurunkan influx Ca, dan tekanan intrakranial. Sehingga dapat mengurangi kerusakan otak dan risiko kematian.

\section{DAFTAR PUSTAKA}

1. Roozenbeek B, Maas AI, Menon DK. Changing patterns in the epidemiology of traumatic brain injury. Nature Reviews Neurology. 2013 Apr;9(4):231.

2. Faul M, Coronado V. Epidemiology of traumatic brain injury. InHandbook of clinical neurology 2015 Jan 1 (Vol. 127, pp. 3-13). Elsevier.

3. Masel BE, DeWitt DS. Traumatic brain injury: a disease process, not an event. Journal of neurotrauma. 2010 Aug 1;27(8):1529-40.

4. Mayer SA, Kowalski RG, Presciutti M, Ostapkovich ND, McGann E, Fitzsimmons BF, Yavagal DR, Du YE, Naidech AM, Janjua NA, Claassen J. Clinical trial of a novel surface cooling system for fever control in neurocritical care patients. Critical care medicine. 2004 Dec 1;32(12):2508-15.

5. Bisri DY, Bisri T. Terapi Hipotermi setelah Cedera Otak Traumatik.

6. Andresen M, Gazmuri JT, Marín A, Regueira T, Rovegno M. Therapeutic hypothermia for acute brain injuries. Scandinavian journal of trauma, resuscitation and emergency medicine. 2015 Dec;23(1):42.

7. Mrozek S, Vardon F, Geeraerts T. Brain temperature: physiology and pathophysiology after brain injury. Anesthesiology research and practice. 2012;2012.

8. Watson HI, Shepherd AA, Rhodes JK, Andrews PJ. Revisited: a systematic review of therapeutic hypothermia for adult patients following traumatic brain injury. Critical care medicine. 2018 Jun 1;46(6):972-9.

9. Yokobori S, Yokota H. Targeted temperature management in traumatic brain injury. Journal of intensive care. 2016 Dec;4(1):28.

10. Johnson VE, Stewart JE, Begbie FD, Trojanowski JQ, Smith DH, Stewart W. Inflammation and white matter degeneration persist for years after a single traumatic brain injury. Brain. 2013 Jan 1;136(1):28-42.

11. Subramanian A, Agrawal D, Pandey RM, Nimiya M, Albert V. The leukocyte count, immature granulocyte count and immediate outcome in head injury patients. InBrain Injury-Pathogenesis, Monitoring, Recovery and Management 2012 Mar 23. IntechOpen.

12. Dardiotis E, Fountas KN, Dardioti M, Xiromerisiou G, Kapsalaki E, Tasiou A, Hadjigeorgiou GM. Genetic association studies in patients with traumatic brain injury. Neurosurgical focus. 2010; 28(1):E9.

13. Sriyanto S. Hubungan antara peningkatan volume hematoma epidural (EDH) dengan peningkatan kadar Glial Fibrilary Acidic Protein (GFAP) plasma (The correlation between epidural hematoma (EDH) volume and GFAP's plasma consentration). Doctoral dissertation. Semarang: Program Pasca Sarjana Universitas Diponegoro. 